\title{
CREscimento Vegetativo E FLOREscimento dE genótipos de GOIABEIRA
}

\author{
Matheus Alves Silva ${ }^{1}$ \\ Séphora Neves da Silva ${ }^{2}$ \\ José Henrique Soler Guilhen ${ }^{3}$ \\ Tiago de Souza Marçal ${ }^{4}$ \\ Adésio Ferreira ${ }^{5}$ \\ Marcia Flores da Silva Ferreira ${ }^{6}$
}

Resumo: Estudos quanto à fenologia dos genótipos, podem ser empregados, visando gerar informações que auxiliem na melhoria e aumento da produção. Nesse trabalho propôs-se como objetivo geral avaliar o crescimento vegetativo e florescimento de genótipos de goiabeira. Para isso, foram utilizados 22 genótipos comerciais cultivados em um experimento instalado no município de Mimoso do Sul, Espírito Santo. O experimento é constituído de blocos casualizados com três repetições. Foram feitas medições do maior ramo obtido em 77, 113, 134 e 217 após a poda com auxílio de trena. Além disso, foram avaliadas presença e ausência de flores abertas em 19, 32, 54, 77, 91, 113, 134, 154 e 217 após a poda. O crescimento médio variou de 0,661 a 0,435 m, havendo diferenças significativas entre os genótipos. Foi possível verificar que alguns genótipos foram mais precoces, outros mais tardios em relação ao período de florescimento, entretanto aos 91 dias após a poda, todos os genótipos apresentaram presença de flores abertas, em todas as repetições. Os resultados obtidos nesse trabalho revelam a possibilidade de alterações de manejo e tratos culturais.

Palavras-chave: Fenologia; Goiaba; Produção.

\footnotetext{
${ }^{1}$ Graduando em Agronomia/Universidade Federal do Espírito Santo, Brasil. E-mail: alvesmatheuss21@gmail.com.

2 Doutoranda em Genética e Melhoramento/Universidade Federal do Espírito Santo, Brasil. E-mail: sephorans@gmail.com.

${ }^{3}$ Doutorando em Genética e Melhoramento/Universidade Federal do Espírito Santo, Brasil. E-mail: jhguilhen@gmail.com.

4 Doutorando em Genética e Melhoramento/Universidade Federal de Viçosa, Brasil. E-mail: tiagosmaragronomia@gmail.com.

${ }^{5}$ Professor Associado/Universidade Federal do Espírito Santo, Brasil. E-mail: adesioferreira@gmail.com.

${ }^{6}$ Professora Associada/Universidade Federal do Espírito Santo, Brasil. E-mail: mfloressf@gmail.com.
} 